\title{
Testbaseret optag til videregående uddannelser
}

Maria Cecilie Vonsild, specialkonsulent, Syddansk Universitet

Agner Holmberg Schibler, AC-fuldmæegtig, Syddansk Universitet

Birgitta Wallstedt, leder af SDU Universitetspæadagogik, Syddansk Universitet

\section{Faglig artikel (bedømt af redaktionen)}

På Syddansk Universitet vil der som led i et nyt projekt blive indfort nye optagelsesprocedurer i forbindelse med bacheloroptaget i 2017. Allerede nu er over 50 bacheloruddannelser på tværs af fakulteterne i færd med at ændre deres nuværende optagelsesprocedurer til i højere grad at anvende tests og samtaler, enten i form af optagelsesprover i kvote 2 eller som adgangsprover, der kan sidestilles med et karakterkrav.

I artiklen beskrives anvendeligheden af skriftlige/mundtlige tests og motiverede ansøgninger samt de lovgivningsmæssige muligheder for indførelse af optagelses- og adgangsprover på de danske universiteter. Der gives eksempler på typer af optagelsestests, der anvendes på universiteter i udlandet, ligesom der præsenteres konkrete eksempler på testindhold og resultater fra den særlige optagelsesprocedure i kvote 2 på Det Sundhedsvidenskabelige Fakultet på SDU. Erfaringer fra andre uddannelsesinstitutioner inddrages også, danske såvel som internationale.

\section{Indledning}

På Syddansk Universitet (SDU) vil der som led i et nyt optagelsesprojekt blive indført optagelses-og adgangsprøver med anvendelse af forskellige typer tests i forbindelse med bacheloroptaget fra 2017. Målet er, at mindst $25 \%$ af de studerende på hvert fakultet skal optages enten på baggrund af adgangsprøver som en del af adgangskravene, eller i form af optagelsesprøver i kvote 2.

Projektet skal udvikle en fælles model - SDU-modellen - for organiseringen af optagelsesog adgangsprøverne. Her har bacheloruddannelserne mulighed for at vælge mellem følgende:

1) fagspecifik test eller 2) både uniTEST og fagspecifik test:

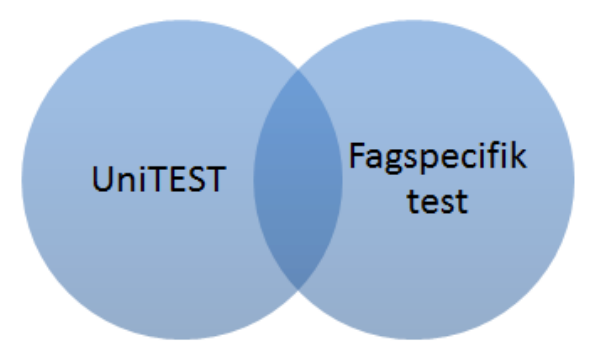


SDU modellen skal leve op til fire grundlæggende kvalitetskriterier. Testene skal være:

1. Valide - Testene skal måle det, som vi ønsker at måle (viden, færdigheder, kompetencer).

2. Pålidelige - Testene skal være retfærdige og konsistente.

3. Acceptable - Testene skal både for ansøgerne og omgivelserne opleves som acceptable.

4. Gennemførlige - Testene skal være praktisk gennemførlige, administrativt effektive og baseret på overvejelser over ressourceanvendelse og økonomi.

Baggrunden for denne artikel er, at der i forbindelse med SDU's nye optagelsesprojekt er opstået et behov for at få præciseret rammerne for de eksisterende muligheder i optagelsessystemet og for hvilke overvejelser, der skal gøres, forud for planlægningen af nye optagelsesprocedurer: Hvad skal testene indeholde, hvilke kompetencer ønsker man at måle, og hvilke tests er bedst egnede til hvilke fagområder?

Udover at efterkomme et lokalt behov for en fælles forståelse for rammer, terminologi og indhold modtager SDU i stigende grad henvendelser fra andre uddannelsesinstitutioner, som ønsker at videreudvikle deres nuværende optagelsessystemer til også at se på andre parametre end kun det adgangsgivende karaktergennemsnit.

Formålet er derfor indledningsvist at beskrive, hvilke muligheder de danske universiteter har for at indføre adgangs- og optagelsesprøver inden for gældende lovgivning, samt præsentere eksempler på forskellige testtyper og på, hvordan de anvendes til optagelse af studerende til videregående uddannelser rundt om i verden. På baggrund heraf vil vi beskæftige os med indholdet af forskellige testtyper (skriftlige og mundtlige tests, motiverede ansøgninger), samt præsentere eksempler på SDU's resultater med anvendelse af særlige optagelsesprocedurer på de sundhedsvidenskabelige uddannelser. Desuden vil erfaringer fra den danske læreruddannelse samt internationale erfaringer blive inddraget.

\section{Eksisterende muligheder i det danske optagelsessystem}

I den gældende bacheloradgangsbekendtgørelse (BEK nr. 257 af 18/3/2015) ${ }^{1}$, beskrives de muligheder, der findes i dag for at indføre testbaseret optag:

1. Karakterkrav samt anvendelse af adgangsprøver, der kan sidestilles med karakterkrav (§5).

2. Kvotefordeling samt anvendelse af samtaler og optagelsesprøver i kvote 2 (§ 23).

${ }^{1}$ https://www.retsinformation.dk/forms/R0710.aspx?id=168839 


\section{Ad. 1.: Karakterkrav}

Efter $\S 5$ kan et universitet kræve, at den adgangsgivende eksamen er gennemført med et bestemt eksamensgennemsnit som minimum, eller at enkelte fag er bestået med en bestemt minimumskarakter højere end 02. Fastsættelse af karakterkrav skal varsles med mindst 2 år, før de får virkning.

Indføres der karakterkrav, vil karakterkravet være en del af adgangskravet. Det er derfor ikke muligt at fastsætte et karakterkrav for kvote 1 ansøgere, som ikke skal gælde for kvote 2 ansøgere. Karakterkravet gælder altså for både kvote 1 og kvote 2 ansøgere.

Ved indførelsen af stk. 2. får universiteterne nu mulighed for at indføre en adgangsprøve som dokumenterer tilsvarende kvalifikationer. Dette er nyt i bacheloradgangsbekendtgørelsen fra marts 2015. Ligesom karakterkravet er en del af adgangskravene, vil adgangsprøven også være en del af adgangskravene. Ansøgere, der ikke opfylder karakterkravet, kan hermed stadig komme i betragtning til en studieplads, hvis de består adgangsprøven på et niveau, som universitetet skønner kan sidestilles med det fastsatte karakterkrav. Adgangsprøven skal opfattes som en erstatning for manglende opfyldelse af et karakterkrav.

\section{Ad. 2.: Kvote 2}

Er der flere ansøgere end studiepladser på bacheloruddannelser med adgangsbegrænsning, opdeles pladserne i kvote 1 og 2. Styrelsen fastsætter hvert år kvoternes størrelse efter indstilling fra universiteterne. Et universitets ønske imødekommes almindeligvis, hvis det ikke strider imod visse rammer herfor ( $\mathrm{fx}$ må studiepladserne ikke fordeles med $100 \%$ i kvote 1 og 0\% i kvote 2). Det er således muligt at introducere en større kvote 2 og/eller øge anvendelsen af optagelsesprøver på en række bacheloruddannelser.

Studiepladserne i kvote 2 tildeles efter en konkret vurdering af ansøgerne på baggrund af objektive, faglige kriterier fastsat af det enkelte universitet. I vurderingen kan der indgå optagelsesprøver, samtaler m.v.

Der kan desuden indgå bestemte fagsnit (karakterer i udvalgte fag) i kvote 2: man kan godt lægge vægt på et bestemt fag, men fagsnittet må ikke stå alene - det skal anvendes i kombination med andre kriterier for at sikre, at der foretages en konkret vurdering af hver enkelt ansøger.

Endelig kan Styrelsen for Videregående Uddannelser godkende, at universitetet på visse bacheloruddannelser anvender et andet optagelsessystem end kvotesystemet (§13, stk. 3). Dette er fx tilfældet på bacheloruddannelserne i J ournalistik.

\section{Særligt for Sundhedsvidenskab:}

På Det Sundhedsvidenskabelige Fakultet har man siden 2008 haft særlig tilladelse til at indføre et karakterkrav som en del af optagelsesproceduren i kvote 2.

Følgende bliver inviteret til test:

Alle ansøgere med et gennemsnit på 6,0 eller derover efter 7-trins skalaen.

Årets dimittender, hvis de opfylder de specifikke adgangskrav for den pågældende bacheloruddannelse. 
Tilbud om studieplads vil dog være betinget af, at ansøgeren opfylder de specifikke adgangskrav til den ansøgte uddannelse senest $d$. 5. juli i optagelsesåret, og at årets dimittender har opnået et gennemsnit fra den adgangsgivende eksamen på mindst 6,0 efter 7-trins skalaen

Hvis andre bacheloruddannelser ønsker at gøre det samme, nemlig sortere ansøgere fra på baggrund af et karakterkrav gældende for kvote 2 alene, skal der indhentes særlig tilladelse hos Styrelsen for Videregående Uddannelser.

\section{Adgangsprøver versus optagelsesprøver}

Det er vigtigt at skelne mellem, om en optagelsesprocedure anvender en adgangsprøve eller en optagelsesprøve, idet der juridisk set er forskel herpå: En optagelsesprøve har til formål at udvælge studerende blandt ansøgere, der alle opfylder adgangskravene. En adgangsprøve derimod er en del af adgangskravene til uddannelsen, idet prøven skal sidestilles med og dermed erstatter karakterkravet til uddannelsen.

\section{Typer af optagelsestests der anvendes på universiteter i udlandet - et over- blik:}

Optagelsestests anvendes i udbredt grad på universiteter verden over, enten som det eneste adgangskrav, eller som supplement til karakterer opnået i en gymnasial uddannelse.

Tests kan være enten generelle eller fagspecifikke og kan anvendes som det eneste adgangsgrundlag eller i kombinationer med hinanden eller med eksamensresultater fra den adgangsgivende eksamen.

Det svenske optagelsessystem har således forskellige veje ind til en videregående uddannelse. Enten vurderes ansøgerne på baggrund af deres karaktergennemsnit fra den adgangsgivende eksamen, eller de vurderes på baggrund af deres resultat fra Högskoleprovet $^{2}$ - en generel adgangstest i MCQ-format. Som en tredje mulighed kan universiteterne anvende andre, selvvalgte optagelsesprocedurer, som fx samtaler eller andre testtyper.

I visse lande, fx i USA og Kina, indgår en fælles, generel adgangstest som et overordnet adgangskrav, hvor ansøgerne skal gennemføre en adgangsprøve som forudsætning for at komme i betragtning til en studieplads. I USA anvendes $\mathrm{fx}$ en generel test for vurdering af akademiske kompetencer (Scholastic Aptitude Test SAT ${ }^{3}$ ) som adgangsprøve til mange forskellige uddannelsesområder.

Tests kan også være fagspecifikke. Særligt inden for det sundhedsvidenskabelige område er det almindeligt at anvende tests til at vurdere kompetencer og/eller personlige egenskaber, der matcher en specifik uddannelse, fx dyrlæge eller læge.

Nedenstående tabeller viser eksempler på henholdsvis generelle tests (tabel 1) og fagspecifikke tests (tabel 2):

\footnotetext{
${ }^{2}$ http://studera.nu/hogskoleprov/det-viktigaste-om-hogskoleprovet/

${ }^{3}$ https://sat.collegeboard.org/home
} 
Tabel 1: Eksempler på generelle tests

\begin{tabular}{|c|c|c|c|c|}
\hline Testtype & I ndhold & Land & Optagelsessystem & \\
\hline \multirow[t]{3}{*}{ uniTEST (ACER) } & \multirow[t]{3}{*}{$\begin{array}{l}\text { Kritisk, kvantitativt og sprog- } \\
\text { ligt ræsonnement }\end{array}$} & Australien & \multirow[t]{3}{*}{$\begin{array}{l}\text { Supplement til formelle ad- } \\
\text { gangskrav }\end{array}$} & Udvalgte universiteter \\
\hline & & DK & & Udvalgte universiteter \\
\hline & & UK & & Udvalgte universiteter \\
\hline $\begin{array}{l}\text { Högskoleprovet } \\
\text { (MCQ) }\end{array}$ & $\begin{array}{l}\text { Kvantitativt ræsonnement og } \\
\text { matematisk problemløsning } \\
\text { Verbal del - ord og læsefor- } \\
\text { ståelse (svensk og engelsk) }\end{array}$ & Sverige & $\begin{array}{l}\text { Mindst } 1 / 3 \text { af alle studerende } \\
\text { på alle universiteter i Sverige } \\
\text { optages på baggrund af } \\
\text { Högskoleprovet }\end{array}$ & Nationalt optagelsessystem \\
\hline \multirow[t]{2}{*}{$\begin{array}{l}\text { Thinking Skills } \text { Asses- } \\
\text { sment (MCQ) }\end{array}$} & \multirow[t]{2}{*}{$\begin{array}{l}\text { Kritisk tænkning og problem- } \\
\text { løsning }\end{array}$} & UK & \multirow[t]{2}{*}{$\begin{array}{l}\text { Supplement til fagspecifikke } \\
\text { testformer }\end{array}$} & \multirow[t]{2}{*}{ Udvalgte universiteter } \\
\hline & & Holland & & \\
\hline $\begin{array}{l}\text { Scholastic Aptitude Test } \\
\text { (MCQ) }\end{array}$ & $\begin{array}{l}\text { Kritisk tænkning og problem- } \\
\text { løsning } \\
\text { Baseret på High School Curri- } \\
\text { culum }\end{array}$ & USA & $\begin{array}{l}\text { Anvendes også i kombination } \\
\text { med SAT Subject Tests }\end{array}$ & $\begin{array}{l}\text { Udvalgte universiteter, men } \\
\text { anvendes bredt på tværs af USA's } \\
\text { stater }\end{array}$ \\
\hline Gaokao (Essay) & $\begin{array}{l}\text { Baseret på High School Cur- } \\
\text { riculum }\end{array}$ & Kina & $\begin{array}{l}\text { Anvendes som en universel } \\
\text { adgangstest }\end{array}$ & Nationalt optagelsessystem \\
\hline
\end{tabular}


Tabel 2: Eksempler på fagspecifikke tests

\begin{tabular}{|c|c|c|c|c|}
\hline Fagspecifik tests indenfor & Testtype & Land & Optagelsessystem & \\
\hline \multirow[t]{9}{*}{ Sundhedsvidenskab } & \multirow[t]{3}{*}{$\begin{array}{l}\text { Medical College Admission test } \\
\text { (MCAT) }\end{array}$} & USA & $\begin{array}{l}\text { Anvendes som en universel } \\
\text { adgangstest }\end{array}$ & Alle medicinuddannelser \\
\hline & & Canada & $\begin{array}{l}\text { Supplement til karaktergen- } \\
\text { nemsnit og andre testformer }\end{array}$ & Udvalgte universiteter \\
\hline & & Australien & $\begin{array}{l}\text { Supplement til karaktergen- } \\
\text { nemsnit og andre testformer }\end{array}$ & Udvalgte universiteter \\
\hline & $\begin{array}{l}\text { Undergraduate Medical Admis- } \\
\text { sions test (UMAT) }\end{array}$ & Australien & $\begin{array}{l}\text { Anvendes som en universel } \\
\text { adgangstest }\end{array}$ & Alle medicinuddannelser \\
\hline & \multirow[t]{4}{*}{ Multiple Mini Interview (MMI) } & Canada & $\begin{array}{l}\text { Supplement til karaktergen- } \\
\text { nemsnit og andre testformer }\end{array}$ & Udvalgte universiteter \\
\hline & & $\overline{U K}$ & $\begin{array}{l}\text { Supplement til karaktergen- } \\
\text { nemsnit og andre testformer }\end{array}$ & Udvalgte universiteter \\
\hline & & DK & $\begin{array}{l}\text { Supplement til adgangsgiven- } \\
\text { de karaktergennemsnit og } \\
\text { uniTEST }\end{array}$ & $\begin{array}{l}\text { Syddansk Universitet siden } 2008 \\
\text { Århus Universitet fra } 2016\end{array}$ \\
\hline & & Australien & $\begin{array}{l}\text { Supplement til karaktergen- } \\
\text { nemsnit og andre testformer }\end{array}$ & Udvalgte universiteter \\
\hline & $\begin{array}{lcc}\text { United } & \text { Kingdom } & \text { Clinical } \\
\text { Aptitude test (UKCAT) } & \end{array}$ & UK & $\begin{array}{l}\text { Supplement til karaktergen- } \\
\text { nemsnit og andre testformer }\end{array}$ & Udvalgte universiteter \\
\hline \multirow[t]{3}{*}{ Jura } & $\begin{array}{l}\text { Law School Admission Test } \\
\text { (LSAT) }\end{array}$ & USA & $\begin{array}{l}\text { Supplement til formelle ad- } \\
\text { gangskrav }\end{array}$ & Udvalgte universiteter \\
\hline & $\begin{array}{l}\text { Law School Admission Test } \\
\text { (LSAT) }\end{array}$ & Canada & $\begin{array}{l}\text { Supplement til formelle ad- } \\
\text { gangskrav }\end{array}$ & Udvalgte universiteter \\
\hline & $\begin{array}{l}\text { National Admissions Test for } \\
\text { Law (LNAT) }\end{array}$ & UK & $\begin{array}{l}\text { Anvendes som en universel } \\
\text { adgangstest }\end{array}$ & Udvalgte universiteter \\
\hline Historie & History Aptitude Test (HAP) & UK & $\begin{array}{l}\text { Supplement til formelle ad- } \\
\text { gangskrav }\end{array}$ & Oxford University \\
\hline Ingeniør & ATN Engineering Test (ACER) & $\begin{array}{l}\text { Australien } \\
\text { (ATNEST) }\end{array}$ & $\begin{array}{l}\text { Anvendes til internationale } \\
\text { ansøgere, æeldre ansøgere, } \\
\text { ansøgere som ikke opfylder de } \\
\text { formelle adgangskrav }\end{array}$ & University og South Australia \\
\hline Matematik & Sixth Term Examination paper & UK & $\begin{array}{l}\text { Supplement til formelle ad- } \\
\text { gangskrav }\end{array}$ & Udvalgte universiteter \\
\hline
\end{tabular}


Fælles for mange af de testtyper som er angivet i tabellerne er, at de er designet til at vurdere ansøgemes evner og studieegnethed. I de fagspecifikke tests er indholdet kontekstvalideret $\mathrm{i}$ forhold til fagområdet. Testene måler $\mathrm{i}$ overvejende grad potentiale og evner (aptitude) for at tilegne sig viden og færdigheder, men de kan også teste færdigheder og viden, som allerede er tilegnet (achievement).

Et eksempel på en achievement test er den kinesiske Gaokao. ${ }^{4}$ UniTEST ${ }^{5}$ er et eksempel på en aptitude test (for at kunne ræsonnere sig frem til det rigtige svar kræves dog allerede tilegnet viden $\mathrm{fx}$ at kunne læse og forstå et koordinatsystem), mens det svenske Högskoleprov indeholder elementer af begge dele. Det er således vanskeligt at opdele de anvendte tests i enten rene aptitude eller rene achievement tests.
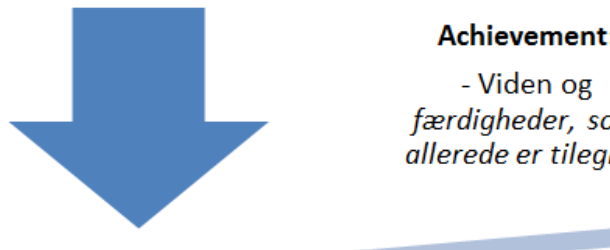

- Viden og færdigheder, som allerede er tilegnet

\section{Optagelsesprocedurers indhold:}

I de følgende afsnit beskrives udvalgte erfaringer og resultater med anvendelse af optagelsesprocedurer, hvori der indgår skriftlige og mundtlige tests samt motiverede ansøgninger:

\section{Skriftlige tests}

En uniTEST har været anvendt siden 2008 på Det Sundhedsvidenskabelige Fakultet, SDU som præselektionstest til udvælgelse af de ansøgere, der går videre til den sidste del af optagelsesproceduren (Multiple Mini Interviews).

UniTEST er udviklet i samarbejde mellem the Australian Council for Educational Research (ACER) og Cambridge Assessment. ACER har over 80 års erfaring i udvikling af adgangsprøver. Testen er en multiple choice questionnaire (MCQ) test der består af 90 spørgsmål og skal gennemføres på 2,5 time. Den er designet til at måle generel studieegnethed inden for 3 udvalgte domæner: Kritisk, kvantitativt og sprogligt ræsonnement.

\section{SDU's erfaringer:}

UniTEST har fungeret med høj grad af reliabilitet (intern konsistens) med en Cronbachs Alpha koefficient på gennemsnitligt 0,86 i de år, den har været anvendt på Sundhedsvidenskab (2008-14). Af graferne nedenfor ses, at uniTEST'en ikke korrelerer med den adgangsgivende kvotient. Disse resultater har været konsistente henover årerne og på tværs af studieretningerne.

\footnotetext{
${ }^{4}$ http://www.slate.com/articles/news and politics/dispatches/2008/06/chinas sat.html

${ }^{5}$ http://unitest.acer.edu.au/
} 

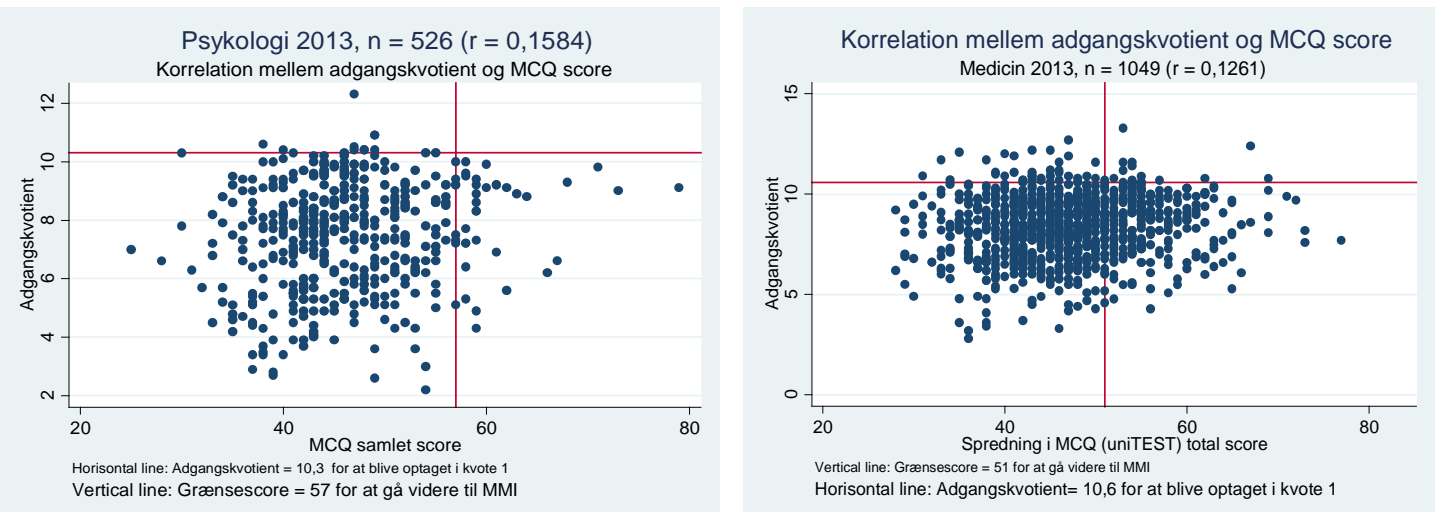

Figur 1: Sammenhængen mellem den adgangsgivende kvotient for ansøgere til henholdsvis medicin- og psykologistudiet og opnået resultat til uniTEST

\section{Effekten af at være udvalgt i kvote 2 kontra optaget i kvote 1}

Der er endnu ikke foretaget separate analyser af uniTESTens prædiktive validitet i forhold til frafald eller andre parametre for akademisk præstation, som fx beståelsesprocent ved førsteårsprøven. Derimod har SDU igennem de sidste 4 år fortaget systematiske evalueringer af sammenhængen mellem at være optaget i kvote 1 eller udvalgt i kvote 2. Evalueringen for perioden 2008-13 viser, at det at være udvalgt i kvote 2 medfører et signifikant mindre frafald efter første og andet studieår og en signifikant højere beståelsesprocent ved førsteårsprøven sammenlignet med de kvote 1 optagne (StudieserviceAnalyse, 2015).

Konklusionen på disse resultater er, at uniTEST bidrager til at måle studieegnethed på en anden måde, end karaktergennemsnittet gør. Dels er der ingen sammenhæng mellem karaktergennemsnittet fra den adgangsgivende eksamen og det opnåede resultat til uniTEST (figur 1); dels klarer de studerende, der er udvalgt i kvote 2, sig mindst lige så godt, eller endnu bedre, end de studerende, der er optaget i kvote 1.

\section{En second chance}

Erfaringerne fra SDU viser også, at anvendelsen af uniTEST har betydning for hvilke ansøgere, der bliver optaget. Af grafen for Psykologi (figur 1) ses, at grænsekvotienten for optagelse i kvote 1 i 2013 var på 10,3 (den vandrette, røde linje), mens grænsescoren for at gå videre til Multiple Mini Interviews var 57 (den lodrette, røde linje). Alle de ansøgere, der befinder sig under den vandrette og til højre for den lodrette linje, ville slet ikke være kommet i betragtning til en studieplads, hvis karaktergennemsnittet fra den adgangsgivende eksamen havde været det eneste adgangskrav. Godt halvdelen af ansøgerne (25) i denne gruppe endte med at få tilbudt en studieplads i kvote 2. Samme billede tegner sig for Medicin, hvor der blev optaget ca. 150 studerende i kvote 2 ud af de ca. 300 der gik videre efter uniTEST. Man kan altså med god ret tale om, at denne testform giver en second chance til de ansøgere, som ikke har tilstrækkeligt høje gennemsnit til at komme ind via kvote 1.

\section{Flere mænd bliver optaget på Medicin}

I nedenstående figur 2 illustreres udvælgelsesproceduren i kvote 2 optagelsen til Medicinstudiet for 2015. Processen består af to runder, hvor første runde er deltagelse i MCQ testen (uniTEST) og anden runde er MMl (Multiple Mini Interview). Ca. 1400 ansøgere deltog i 1 . runde og ca. 300 gik videre til 2 . runde, hvorefter halvdelen fik tilbudt en stu- 
dieplads. De blå og røde søjler viser, at der var væsentligt flere kvindelige end mandlige deltagere i 1. runde (MCQ testen), men fordi mændene klarede sig bedre, betød dette en næsten ligelig kønsfordeling i 2. runde, hvor begge køn klarede sig lige godt.

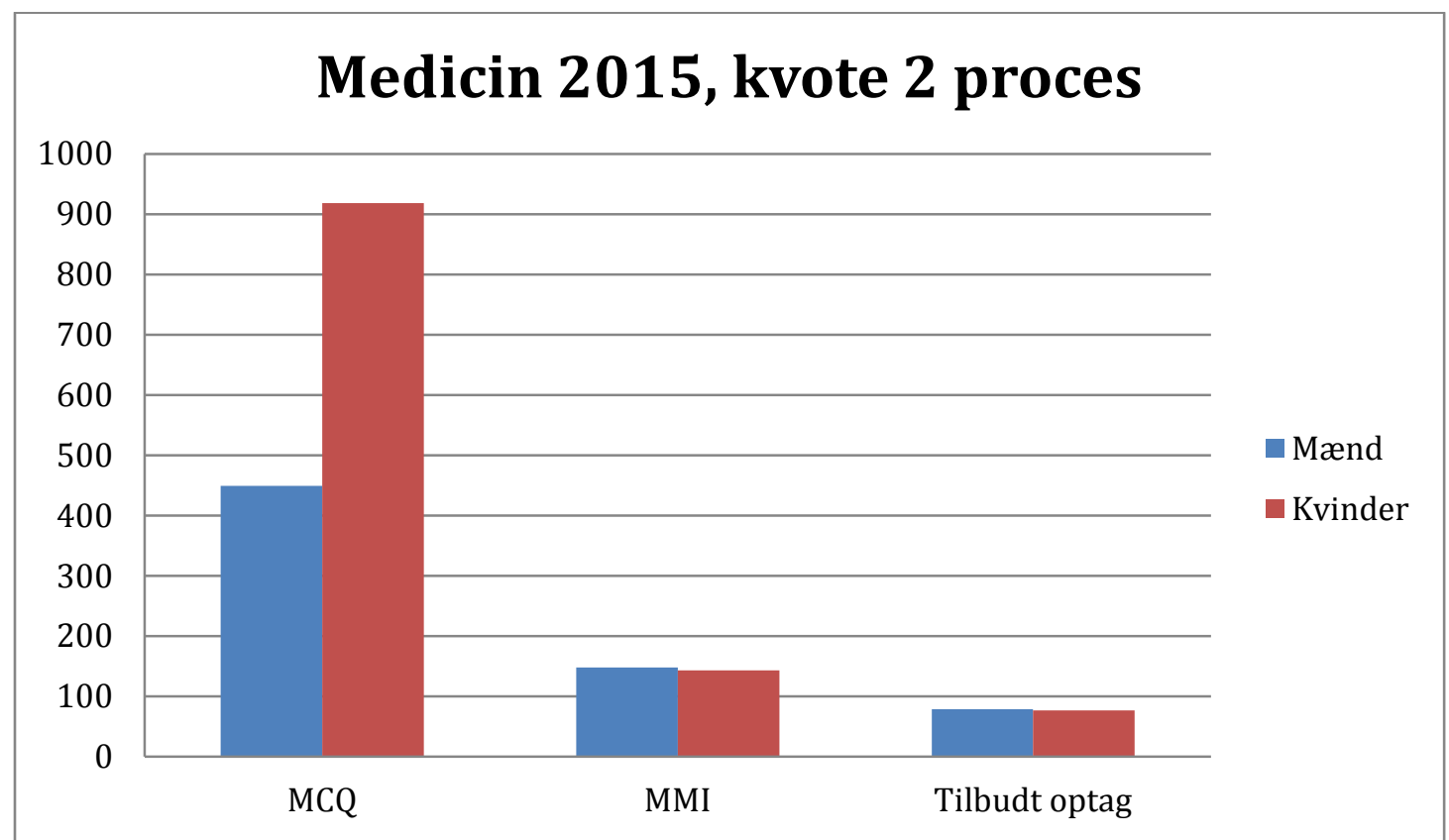

Figur 2: Optagelsesproceduren i kvote 2 til medicinstudiet på Syddansk Universitet i 2015

\section{Selektionseffekt}

Til MCQ testen i år havde i alt 2918 ansøgere til Psykologi, Folkesundhedsvidenskab, Medicin og Klinisk Biomekanik tilmeldt sig via SDU's digitale system. Men på dagen for testens afholdelse mødte kun 2230 op, altså en udeblivelsesprocent på 23,6\%.

En mulig forklaring på udeblivelse, som vi har undersøgt, er prioritet af uddannelse. For en ansøger, der har en uddannelse som 1. prioritet, viser fig. 3, at sandsynligheden for at vedkommende møder op til test er $>80 \%(0,8)$. Har ansøgeren derimod uddannelsen som 4. prioritet, er sandsynligheden for fremmøde $60 \%$ (figur 3 ).

Der synes altså at være en direkte sammenhæng mellem sandsynligheden for fremmøde og ansøgernes prioritet. 


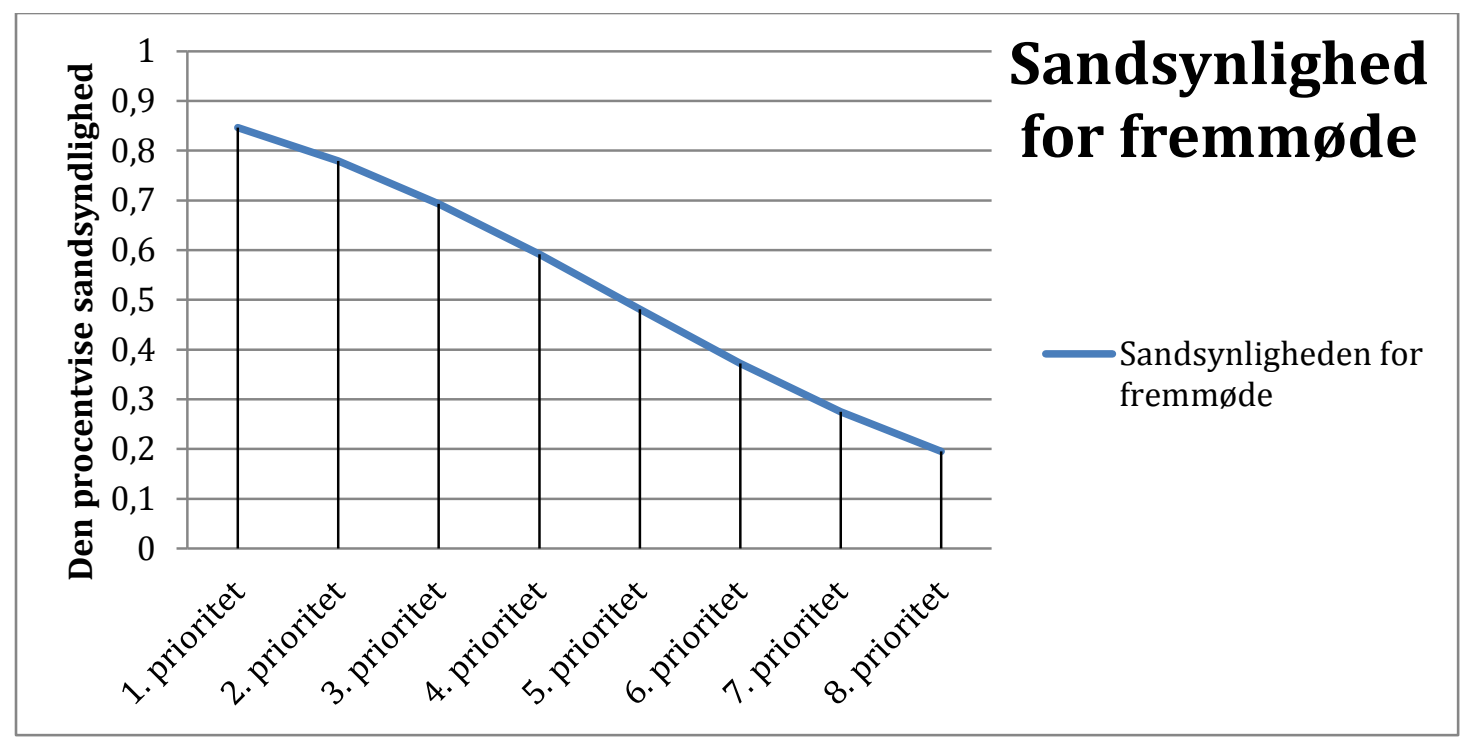

Figur 3: Sandsynligheden for at møde op til test vs. prioritet af uddannelse

På Læreruddannelsen, hvor man i 2013 indførte testbaseret optag, skal ansøgerne selv tilmelde sig optagelsesprøven. Op til 22\% tilmelder sig ikke, hvilket indebærer en markant selvselektion forud for selve optagelsesprøven (Styrelsen for Videregående Uddannelser, 2015). Det at skulle booke et møde, eller møde op til en test, er altså i sig selv en måde at sortere blandt ansøgere, som måske ikke er tilstrækkeligt motiverede for den uddannelse, de har søgt ind på.

\section{Internationale erfaringer}

UniTEST er valideret på australske studerende på seks forskellige universiteter. I en evaluering af testens prædiktive validitet i forhold til studiesucces fandt man, at resultat opnået ved uniTEST forklarede mere variation i opnåede karakterer på universitetet efter et års studietid end karaktergennemsnit fra det, der svarer til en gymnasial eksamen ( 12. års karaktergennemsnit). Yderligere fandt man, at kombinationen af 12. års karaktergennemsnit og UniTEST resultatscore, viste en stærkere sammenhæng med opnåede karakterer på universitetet end 12. års karaktergennemsnit eller uniTEST resultat alene (Coates et al., 2010).

\section{Mundtlige tests}

Et eksempel på en evidensbaseret mundtlig testtype er de såkaldte Multiple Mini Interviews (MMI), som er udviklet på Michael DeGroote School of Medicin på McMaster University i Canada (Eva et al., 2004) og sidenhen anvendt som optagelsesprocedure på en lang række medicinuddannelser (Brownell et al., 2007; Harris \& Owen, 2007; Hecker et al., 2009). Et MMI-forløb består typisk af 6 - 8 stationer, hvor hver ansøger starter samtidig med de andre ansøgere, men ved hver deres station. Interviewet varer 8-10 minutter, og når interviewet er slut ved én station, roterer ansøgerne videre til den næste station. Der er én interviewer ved hver station. Styrken ved anvendelse af denne type af strukturerede optagelsessamtaler er kontekstuafhængighed, fordi bedømmelsen af én færdighed ved én MMI-station ikke påvirker den næste MMI-station, og at der er mange bedømmere, hvilket øger reliabiliteten (Eva et al., 2004).

Indholdsvalideringen af MMl foretages ved hjælp af et uddannelsesspecifikt blueprint, hvor der genereres en matrix for de kriterier, ansøgerne skal bedømmes på ved de en- 
kelte samtalestationer. Blueprintet er udarbejdet af et fagligt ekspertpanel med det primære formål at sikre det optimale match mellem den studerende og uddannelsen.

\section{Internationale erfaringer}

Forskningen viser, at MMI-testen har en høj reliabilitet og er prædiktiv i forhold til kliniske færdigheder og præstation ved den afsluttende embedseksamen, hvor kliniske og kommunikative færdigheder testes (Eva et al., 2009; LeMay et al., 2007; Reiter et al., 2007; Roberts et al., 2009).

\section{Motiverede ansøgninger}

En anden måde at udvælge ansøgere på er brugen af motiverede ansøgninger i kvote 2 . Denne metode er temmelig udbredt, både udenlands og herhjemme.

Måden, hvorpå motiverede ansøgninger indgår i optagelsesproceduren, er meget forskellig. Typisk anvendes de som en del af en kvote 2 procedure som supplement til karakterkrav i særligt relevante fagkombinationer. På nogle uddannelser er den motiverede ansøgning et formelt krav i ansøgningen og anvendes som præselektion til at udvælge de ansøgere, der skal gå videre til det næste led i optagelsesproceduren.

Nogle uddannelser, fx J ournalistuddannelsen i Århus, anvender den motiverede ansøgning i en udvælgelsessamtale med de ansøgere, der har deltaget i den første del af optagelsesprøven, men som ikke fik point nok til at blive optaget direkte.

\section{SDU's erfaringer}

På Det Sundhedsvidenskabelige Fakultet anvendte man i årerne 2002-07 motiverede ansøgninger som præselektion til Klinisk Biomekanik, Medicin og Idræt \& Sundhed. Den motiverede ansøgning blev indsendt sammen med den formelle kvote 2 ansøgning og vurderet af to bedømmere. Det viste sig dog, at der var væsentlige problemer ved anvendelse af denne metode: I forhold til validitet har brugen af motiverede ansøgninger grundlæggende det problem, at der ingen sikkerhed er for, at ansøgningen er skrevet af ansøgeren selv. Den kunne lige så vel være skrevet/redigeret af andre, eller direkte fabrikeret af en spøgelsesskribent. Så længe en motiveret ansøgning ikke skrives under kontrollerede forhold, har bedømmerne ingen garanti for, at ansøgningen er skrevet af rette vedkommende, og dermed er validiteten særdeles tvivlsom.

Reproducerbarheden af bedømmelsen af de motiverede ansøgninger blev undersøgt i en ph.d.-afhandling om optagelsesproceduren på Sundhedsvidenskab i 2007. Resultatet viste så høj grad af uoverensstemmelse i bedømmelsen af ansøgningerne (foretaget af to bedømmere), at resultatet for generaliserbarhed $(G=0,10)$ lå væsentligt under den acceptable grænse. Til sammenligning blev der fundet god generaliserbarhed ved anvendelsen af strukturerede samtaler og for kombinationen af vurdering af kvalifikationer, samtale og paratvidentest ( $G=0,82$ ) (O'Neill et al., 2009).

Derudover kan det være en særdeles administrativ tung og ressourcekrævende opgave at læse motiverede ansøgninger igennem, især hvis der skal være mindst to bedømmere per ansøgning.

Til trods for den meget udbredte anvendelse af motiverede ansøgninger, findes der kun ganske sparsom forskning i brugen af samme, der understøtter, at dette er en pålidelig og valid måde at udvælge og frasortere kommende studerende på (Ferguson et. al., 2000; Salvatori et al., 2001; Oosterveld \& ten Cate, 2004; Wouters et. al., 2014). 


\section{Konklusion}

Inden for rammerne af gæeldende lovgivning har universiteterne følgende muligheder for at indføre optagelsesprocedurer, hvor ansøgere kan blive vurderet på andre parametre end karakterer:

- $\quad$ Adgangsprøver, som en del af adgangskravene, hvor resultatet af prøven erstatter et givent minimumskarakterkrav.

- $\quad$ Optagelsesprøver i kvote 2, hvor formålet er at udvælge blandt ansøgere, der alle opfylder de formelle adgangskrav.

- $\quad$ Vælge et andet optagelsessystem end kvotesystemet (kræver dog særlig tilladelse fra Styrelsen for Videregående Uddannelser).

Anvendelsen af testbaseret optag er særdeles udbredt rundt om i verden. Her er tests typisk generelle eller fagspecifikke, og de anvendes til at vurdere studieegnethed. Indholdet kan enten være baseret på vurdering af generelle eller specifikke færdigheder, der allerede er indlært (achievement), eller de kan være designet til at vurdere potentiale og evner til at kunne tilegne sig generelle eller specifikke faglige færdigheder (aptitude).

Når en testtype skal vælges, er det derfor vigtigt at gøre sig overvejelser omkring, hvad det er, testen skal kunne måle:

- $\quad$ Er det generelle/specifikke kompetencer uddannelsen kræver - eller en kombination af begge dele?

- $\quad$ Er det vigtigt, at ansøgeren allerede har en tilegnet færdighed, eller er det evnerne til at kunne tilegne sig de kompetencer som uddannelsen kræver?

Når disse tanker er gjort, skal der vælges en eller flere tests, der måler det (viden, færdigheder, kompetencer), som uddannelsen ønsker at måle. I denne artikel er vi gået særligt i dybden med indholdet og anvendeligheden af følgende testtyper:

1) Skriftlig test: uniTEST, en aptitude test, kan anvendes til at vurdere generel studieegnethed indenfor tre overordnede domæner: kritisk, kvantitativt og sprogligt ræsonnement. Testen fungerer med høj grad af reliabilitet og er på SDU blevet anvendt til at teste op til 3000 ansøgere på én og samme dag.

2) Mundtlig test: Multiple Mini Interview, kan anvendes som en fagspecifik test til at matche kompetencer, motivation, og personlige egenskaber specifikt til en uddannelses kompetenceprofil. Interviewformatet fungerer med rimelig grad af pålidelighed, og internationale studier har dokumenteret, at denne testform prædikterer senere studiesucces.

3) Motiverede ansøgninger: Tvivlsom validitet, reproducerbarhed og gennemførlighed medfører oftest manglende acceptabilitet blandt bedømmere, ledere og andre primære interessenter. Hvordan motiverede ansøgninger anvendes i en optagelsesprocedure bør derfor overvejes nøje. Motiverede ansøgninger kan vise sig anvendelige og informative, hvis de anvendes som udgangspunkt for en optagelsessamtale, mens metoden er kontroversiel, hvis den anvendes som det eneste parameter til at sortere ansøgere fra. 
I denne artikel har vi valgt at beskæftige os med de lovgivningsmæssige rammer, samt indhold og anvendelsesmuligheder af forskellige typer af tests til vurdering af ansøgeres kognitive evner og faglige potentiale for at kunne gennemføre og fuldføre en videregående uddannelse.

Vi vil afslutningsvis understrege, at udfoldelsen af de nye optagelsesprocedurer på Syddansk Universitet har et særligt fokus på at finde det rette match mellem den specifikke uddannelse og den studerende igennem tests og samtaler, der vurderer både evner og vilje for det specifikke studievalg. SDU-modellen har i denne kontekst en central funktion i forhold til at sikre, at de ansøgere, der vurderes, også besidder en indre drivkraft og motivation, der kan bære dem igennem et videregående uddannelsesforløb. Ansøgernes vilje til at møde op til en krævende test, samt deltagelse i fagspecifikke tests og samtaler, hvor deres personlige overvejelser og viden om uddannelsens relaterede indhold bringes i spil, vil således kunne afspejle såvel indre som ydre motivation for at vælge en specifik uddannelse.

Maria Cecilie Vonsild er uddannet cand. scient. og ansat som specialkonsulent i StudieserviceSekretariat. Maria er projektleder for implementering af de nye optagelsesprocedurer på Syddansk Universitet.

Agner Holmberg Schibler er uddannet cand.scient.pol og ansat som AC-fuldmægtig i Studieservice-Analyse på Syddansk Universitet.

Birgitta Wallstedt er uddannet cand.scient. og er ansat som kontorchef og leder af SDU Universitetspæedagogik på Syddansk Universitet.

\section{Litteratur}

Brownell, K., Lockyer, J., Collin, T. \& Lemay, J. F. (2007). Introduction to the multiple mini interview into the admissions process at the University of Calgary: Acceptability and feasibility. Medical Teacher, 29, 394-396.

Coates, H., Edwards, D. \& Friedman, T. (2010). Student aptitude test for tertiary admission (SATTA) pilot program. Evaluation report for the Department of Education, Employment and Workplace Relations (DEEWR). Australian Council for Educational Research.

Emery, J. L. \& Shannon, M. D. (2007). The predictive validity of the Thinking Skills Assessment: A combined analysis of the three cohorts. Admission Testing Service.

Eva, K. W., Rosenfeld, J., Reiter, I.H. \& Norman, G. R. (2004). An admissions OSCE: The multiple mini interview. Medical Education, 38, 314-326.

Eva, K. W., Reiter, I.H., Trinh, K., Wasi, P., Rosenfeld. J. \& Norman, G. R. (2009). Predictive validity of the multiple mini interview for selecting medical trainees. Medical Education, 43(8), 767-775.

Ferguson, E., Sanders, A., O'Hehir, F. \& James, D. (2000). Predictive validity of personal statements and the role of the five-factor model of personality in relation to medical training. Journal of Occupational and Organizational Psychology, 73(3), 321-344.

Harris, S. \& Owen, C. (2007). Discerning quality: Using the multiple mini interview in student selection for the Australian National University Medical School. Medical Education, 41(3), 234-241. 
Hecker , K., Donnon, T., Fuentealba, C., Hall, D., Illanes, O., Morck, D. W. \& Muelling, C. (2009). Assessment of applicants to the veterinary curriculum using a multiple mini-interview method. Journal of Veterinary Medical Education, 362), 166-173.

LeMay, J. F., Lockyer, J. M., Collin, V. T. \& Brownell, A. K. (2007). Assessment of noncognitive traits through the admissions multiple mini-interview. Medical Education, 41(6), 573-579.

O’Neill, L., Korsholm, L., Wallstedt, B., Eika, B. \& Hartvigsen, J. (2009). Generalizability of a composite student selection program. Medical Education, 43, 58-65.

Oosterveld, P. \& ten Cate, O. (2004). Generalizability of a study sample assessment procedure for entrance selection for medical school. Medical Teacher, 267), 635639.

Reiter, H. J., Eva, K.W., Rosenfeld, J. \& Norman, G. R. (2007). Multiple Mini Interview predict clerkship and licensing examination performance. Medical Education, 41(4), 378-384.

Roberts, C., Zoenetti, N. \& Rothnie, J. (2009). Validating a multiple mini-interview question bank assessing entry-level reasoning skills in candidates for graduateentry medicine and dentistry programmes. Medical Education, 43(4), 350-359.

Salvatori, P. (2001). Reliability and validity of admission tools used to select students for the health professions. Advances in Health Science Education: Theory and Practice, 62), 159-75.

Studieservice-Analyse, Syddansk Universitet. (2015). Dokumentation til evaluering af kvote 2 - proces. Intern rapport.

Styrelsen for Videregående Uddannelser (2015). Evaluering af optagelsessamtalerne på læreruddannelsen - optaget 2014. København: Styrelsen for Videregående Uddannelser, Uddannelses- og Forskningsministeriet.

Wouters, A., Bakker, A. H., van Wijk, I. J., Croiset, G. \& Kusurkar, R. A. (2014). A qualitative analysis of statements on motivation of applicants for medical school. BMC Medical Education,14, 1-11. 